\title{
Effects of Alfalfa Particle Size and Specific Gravity on Chewing Activity, Digestibility, and Performance of Holstein Dairy Cows
}

\author{
A. Teimouri Yansari, ${ }^{1, *}$ R. Valizadeh, ${ }^{1}$ A. Naserian, ${ }^{1}$ D. A. Christensen, ${ }^{2}$ \\ P. $\mathrm{Yu}^{2}$ and F. Eftekhari Shahroodi ${ }^{1}$ \\ ${ }^{1}$ Department of Animal Science, Agricultural Faculty, \\ Ferdowsi University of Mashhad, Iran \\ ${ }^{2}$ Department of Animal and Poultry Science, \\ University of Saskatchewan, 51 Campus Drive, \\ S7N5A8, Saskatoon, Canada
}

\begin{abstract}
Two experiments were carried out to test the effects of alfalfa particle size and functional specific gravity (FSG) on chewing activity, digestibility, rumen kinetics, and production of lactating dairy cows fed corn silage based rations. In experiment 1, water-holding capacity (WHC), insoluble dry matter, hydration rate, and FSG changes were determined in alfalfa hay (varying in particle size) and corn silage. Reduction of particle size increased bulk density, FSG, and the rate of hydration, and decreased WHC of alfalfa. In experiment 2, 9 midlactation Holstein dairy cows fed total mixed rations containing 3 sizes of alfalfa hay (with geometric mean $7.83,4.04$, and $1.14 \mathrm{~mm}$ ) were used in a replicated $3 \times 3$ Latin square design. The diets contained $20,20,35,7,7.5,10,0.3,0.1$, and $0.1 \%$ of DM alfalfa, corn silage, barley, soybean meal, beet pulp, wheat bran, dicalcium phosphate, vitamin premix, and salt, respectively. The geometric means (GM) of rations were $3.34,2.47$, and $1.66 \mathrm{~mm}$ in long, medium, and fine alfalfa treatments, respectively. Reduction of particle size increased daily NDF intake $(\mathrm{kg})$, but decreased the proportion of physically effective factor (pef) and physically effective NDF (peNDF) in the ingested rations. Reduction of particle size increased the FSG of rations and intake of DM but reduced digestibility of NDF and ash. Reduction of particle size decreased ruminal mean retention time (RMRT), but increased the ruminal particulate passage rate. Milk and FCM yield were not affected by treatments. The rumen $\mathrm{pH}$, total chewing activity, rumination, eating time, and milk fat were reduced as
\end{abstract}

Received August 28, 2003.

Accepted May 7, 2004.

Corresponding author: A. Teimouri Yansari; e-mail: astymori@ yahoo.com.

*Current address: Department of Animal and Poultry Science, University of Saskatchewan, 51 Campus Drive, S7N5A8, Saskatoon, Canada. particle size decreased, but milk protein increased. This study showed that reduction of forage particle size increased bulk density, FSG, and hydration rate of alfalfa and was the most influential factor affecting DMI, milk composition, and chewing behavior. Reduction of forage particle size had minimal impact on digestibility and milk production.

(Key words: particle size, functional specific gravity, physically effective NDF, dairy cow)

Abbreviation key: FSG = functional specific gravity, GM = geometric mean, pef = physically effective factor, $\mathbf{p e N D F}=$ physically effective NDF, pef $_{>\mathbf{1 . 1 8}}=$ pef determined as percentage of DM remaining on a 1.18$\mathrm{mm}$ screen using a dry sieving technique, pef $\mathbf{f}_{\text {PSPSorigi- }}$ nal and pef $_{\text {PSPSnew }}=$ pef calculated as sum of DM on 2 and 3 sieves in original and new versions of PSPS, respectively, PSPS $=$ Penn State Particle Separator, RMRT = ruminal mean retention time, $\mathbf{T M R T}=$ total mean retention time, $\mathbf{W H C}=$ water holding capacity .

\section{INTRODUCTION}

Optimal utilization of diets by dairy cows is influenced by the chemical composition and physical characteristics of the ration. Neutral detergent fiber measures some chemical characteristics, but not physical characteristics of fiber such as particle size and density. These physical characteristics can influence nutrient utilization, ruminal fermentation, and animal production independently of the amount or composition of NDF. The physical characteristics become critical when attempting to define the lower limit for acceptable forage: concentrate ratio in dairy rations (Mertens, 1997).

Introduction of physically effective NDF (peNDF) as a fiber portion of the diet that stimulates chewing activity and is responsible for ruminal mat formation is reflected in chemical and physical feed characteristics (Mertens, 1997). Particles should be retained in the rumen to be effective. Particle size and specific 
gravity accounted for 28 and $59 \%$, respectively, of the variation in ruminal mean retention time (RMRT) of plastic particles in sheep (Kaske and Engelhardt, 1990). According to critical size theory, particles longer than $1.18 \mathrm{~mm}$ have the greatest resistance to passage and are largely responsible for stimulating chewing and rumination (Poppi et al., 1980). A sufficient supply of long particles or NDF must be in the ration to increase total chewing activity, maintain rumen $\mathrm{pH}$, optimize rumen environment for digestion, increase acetate: propionate ratio, increase milk fat concentration, and avoid metabolic disorders (Mertens, 1997, 2000). Particles with a density range of 1.2 to 1.5 have the highest rate of passage in cattle (Murphy et al., 1989) and sheep (Kaske and Engelhardt, 1990). Particles with a specific gravity less than 1.2 are likely to float, and those more than 1.5 are likely to sink in the rumen (Murphy et al., 1989; Kaske and Engelhardt, 1990).

Forage particle functional specific gravity (FSG) is altered by exposure to ruminal conditions (Wattiaux, 1990). Two processes in rumen that increase the FSG of particles are liquid uptake and particle size reduction. Both particle size and specific gravity should be used to define escapable and nonescapable rumen fiber fractions (Allen and Mertens, 1988). The nonescapable fraction consists of particles that have an FSG less than the rumen fluid (Allen and Mertens, 1988) and size greater than the critical size (Poppi et al, 1980). The escapable fraction consists of particles that are denser than the rumen fluid and are below the threshold size for retention. In addition, digestibility is directly proportional to the digestible fraction of fiber and rate of fiber digestion, but inversely related to rate of release of particles from nonescapable to escapable fiber pool and rate of escape. The rate of release from fiber fractions is a function of the rate of change in FSG and the rate of particle size breakdown (Allen and Mertens, 1988). Particle size reduction increases the release rate from the nonescapable fraction which results in reduced digestibility. Ruminal particulate matters are mostly below the threshold size for escape; therefore, particle size reduction may not be the ratelimiting step in clearance from the reticulorumen (Kaske and Engelhardt, 1990). High FSG of feeds seems to reduce the amount of fiber in ruminal mat and affects escapable particle retention (Allen and Mertens, 1988). For stimulation of chewing activity and ruminal mat formation and maintenance of mat consistency, particles must be retained in the rumen. However, Kaske and Engelhardt (1990) found that FSG is a better indicator of retention than particle size.

As the chewing time is based on animal experimentation, an alternative approach to assessing the physically effective factor (pef) of feeds is to determine the proportion of the feed retained on a 1.18-mm sieve (Mertens, 1997). Mertens (1997) recommended multiplying the pef of the diet by its NDF content to calculate peNDF. Several physical feed properties influence pef, but only particle size measurement is mutual to all effective fiber systems.

The objectives of this study were to determine the effects of forage particle size on physical feed characteristics and to evaluate the particle size and FSG of forage on digestibility, total chewing activity, ruminal characteristics, and performance of midlactation Holstein dairy cows.

\section{MATERIALS AND METHODS}

\section{Kinetics of Hydration Measurement}

Sample preparation. Alfalfa (at 15\% flowering, harvested from a single field on one day without rain) was cut and dried. Individual rectangular bales (average weight $=10 \mathrm{~kg}$ ) were chopped with a forage field harvester (Jaguar \#62, Claas Company, Germany) for theoretical cut lengths of 19 and $10 \mathrm{~mm}$ for preparation of long and medium particle size; the fine particles were prepared by milling $10-\mathrm{mm}$ alfalfa using a farm grinder with a 2-mm screen (Miller \#11.02, Behsaz Company, Iran). Bulk density ( $\mathrm{g} / \mathrm{mL})$, insoluble DM (\%), and water-holding capacity (WHC) of 3 alfalfa types and corn silage were measured according to Giger-Reverdin (2000; Table 1). Chemical compositions of 3 sizes of alfalfa and corn silage were determined (AOAC, 2002; Table 1). The distributions of 3 sizes of alfalfa and corn silage were measured using the American Society of Agricultural Engineers (ASAE, 2002) sieves (Table 1) and the original (Lammers et al., 1996) and new (Kononoff, 2002) Penn State Particle Separator (PSPS) sieves.

The kinetics of hydration and FSG. Kinetics of hydration and change in FSG of forages were measured using a $100-\mathrm{mL}$ pycnometer at $39.0 \pm 0.5^{\circ} \mathrm{C}$ (Wattiaux, 1990). Mixed rumen fluid from 2 steers fed only alfalfa was collected prior to feeding and rinsed through 8 layers of cheese cloth, and centrifuged at $30,000 \times g$ for $10 \mathrm{~min}$. The supernatant (with density $1.0068 \pm 0.0005 \mathrm{~g} / \mathrm{mL}$ ) was used as hydration solution. Sodium azide $(0.50 \mathrm{~g} / \mathrm{L})$ and penicillin $\mathrm{G}(25,000 \mathrm{U} /$ $\mathrm{L})$ were added to the hydration solution to prevent microbial growth. Approximately $1.5 \mathrm{~g}$ of each sample, in 5 replicates, was weighed in a pycnometer. The pycnometer was half-filled to allow vigorous shaking after initial soaking of the sample and for removal of gas bubbles. The first reading of the total weight of the pycnometer was taken after $6 \mathrm{~min}(0.1 \mathrm{~h})$ of initial soaking, the shortest interval necessary to eliminate all gas bubbles. After completely filling the pycnome- 
Table 1. Chemical composition and physical characteristics of 3 sizes of alfalfa, corn silage, and 3 TMR containing 3 sizes of alfalfa.

\begin{tabular}{|c|c|c|c|c|c|c|c|}
\hline & \multicolumn{3}{|c|}{ Alfalfa in the treatments } & \multirow[b]{2}{*}{ Corn silage } & \multicolumn{3}{|c|}{ TMR containing alfalfa } \\
\hline & Long & Medium & Fine & & Long & Medium & Fine \\
\hline \multicolumn{8}{|c|}{ Chemical composition (\% of DM) } \\
\hline $\mathrm{CP}$ & 16.48 & 16.49 & 16.50 & 9.00 & 17.11 & 17.13 & 17.16 \\
\hline $\mathrm{NDF}$ & 45.16 & 45.18 & 45.16 & 46.32 & 32.86 & 32.90 & 33.00 \\
\hline $\mathrm{ADF}$ & 31.53 & 31.50 & 31.51 & 29.34 & 22.51 & 22.50 & 22.50 \\
\hline $\mathrm{NFC}$ & 32.98 & 32.98 & 32.99 & 34.41 & 42.93 & 42.84 & 42.73 \\
\hline Ether extract & 1.49 & 1.50 & 1.51 & 3.23 & 1.89 & 1.91 & 1.88 \\
\hline Ash & 3.89 & 3.73 & 3.84 & 7.11 & 5.21 & 5.22 & 5.23 \\
\hline \multicolumn{8}{|l|}{ Physical characteristics $^{1}$} \\
\hline Bulk density $\left(\mathrm{g} / \mathrm{cm}^{3}\right)$ & $0.34^{\mathrm{b}}$ & $0.39^{\mathrm{b}}$ & $0.53^{\mathrm{a}}$ & $0.32^{\mathrm{b}}$ & $0.65^{\mathrm{C}}$ & $0.74^{\mathrm{B}}$ & $0.84^{\mathrm{A}}$ \\
\hline FSG & $1.18^{\mathrm{d}}$ & $1.26^{\mathrm{c}}$ & $1.34^{\mathrm{a}}$ & $1.31^{\mathrm{ab}}$ & $1.39^{\mathrm{C}}$ & $1.47^{\mathrm{B}}$ & $1.56^{\mathrm{A}}$ \\
\hline IDM (\% of DM) & $73.14^{\mathrm{a}}$ & $71.87^{\mathrm{b}}$ & $67.68^{\mathrm{c}}$ & $67.68^{\mathrm{c}}$ & $\ldots$ & $\ldots$ & $\ldots$ \\
\hline WHC (g/g IDM) & $2.92^{\mathrm{b}}$ & $2.81^{\mathrm{b}}$ & $2.74^{\mathrm{c}}$ & $3.85^{\mathrm{a}}$ & 2.12 & 2.05 & 1.98 \\
\hline pef $_{>1.18}$ & $0.95^{\mathrm{a}}$ & $0.82^{\mathrm{b}}$ & $0.44^{\mathrm{c}}$ & $0.83^{\mathrm{b}}$ & $0.71^{\mathrm{A}}$ & $0.62^{\mathrm{B}}$ & $0.46^{\mathrm{C}}$ \\
\hline pef $f_{\text {PSPSoriginal }}$ & $0.64^{\mathrm{a}}$ & $0.47^{\mathrm{b}}$ & $0.00^{\mathrm{c}}$ & $0.40^{\mathrm{b}}$ & $0.34^{\mathrm{A}}$ & $0.17^{\mathrm{B}}$ & $0.06^{\mathrm{C}}$ \\
\hline pef PSPSnew & $0.94^{\mathrm{a}}$ & $0.78^{\mathrm{b}}$ & $0.42^{\mathrm{c}}$ & $0.92^{\mathrm{a}}$ & $0.76^{\mathrm{A}}$ & $0.69^{\mathrm{B}}$ & $0.52^{\mathrm{C}}$ \\
\hline \multicolumn{8}{|c|}{ Particle size distribution $^{2}(\%$ of DM) } \\
\hline $19 \mathrm{~mm}$ & 34.55 & 18.52 & 0.00 & 6.03 & 11.19 & 4.56 & 1.56 \\
\hline $12.7 \mathrm{~mm}$ & 9.25 & 7.70 & 0.00 & 8.28 & 9.26 & 5.68 & 3.76 \\
\hline $6.3 \mathrm{~mm}$ & 8.45 & 10.93 & 0.00 & 18.32 & 6.68 & 10.25 & 4.21 \\
\hline $3.96 \mathrm{~mm}$ & 23.04 & 10.97 & 1.85 & 34.51 & 21.02 & 18.71 & 14.12 \\
\hline $1.18 \mathrm{~mm}$ & 20.27 & 33.87 & 41.17 & 16.35 & 22.93 & 22.56 & 22.28 \\
\hline Pan & 5.44 & 18.01 & 55.98 & 16.51 & 28.92 & 38.25 & 54.07 \\
\hline $\mathrm{GM}^{3}$ & $7.83^{\mathrm{a}}$ & $4.04^{\mathrm{b}}$ & $1.14^{\mathrm{c}}$ & $4.41^{\mathrm{b}}$ & $3.34^{\mathrm{A}}$ & $2.47^{\mathrm{B}}$ & $1.66^{\mathrm{C}}$ \\
\hline Standard deviation of GM & $0.58^{\mathrm{a}}$ & $0.59^{\mathrm{a}}$ & $0.17^{\mathrm{b}}$ & $0.58^{\mathrm{a}}$ & $0.60^{\mathrm{A}}$ & $0.54^{\mathrm{B}}$ & $0.43^{\mathrm{C}}$ \\
\hline
\end{tabular}

a,b,c Means (for 3 sizes of alfalfa and corn) within a row with different superscripts differ $(P<0.05)$.

A,B,C Means (between the rations) within a row with different subscripts differ $(P<0.05)$.

${ }^{1} \mathrm{FSG}=$ Functional specific gravity; IDM = insoluble dry matter; WHC = water-holding capacity measured

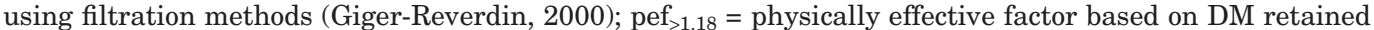
on 1.18-mm sieve (Mertens, 1997); pef PSPSoriginal = physically effective factor determined as the proportion of DM retained on sieves of the original version of PSPS (Lammers et al., 1996); pef PSPSnew $=$ physically effective factor determined as the proportion of DM retained on sieves of the new version of PSPS (Kononoff, 2002).

${ }^{2}$ Particle size distribution = material retained on each ASAE S424.1 sieve as \% of DM (ASAE S424.1, 2002)

${ }^{3} \mathrm{GM}=$ Geometric mean of particle size $(\mathrm{mm})$.

ter, it was again placed on the stirring plate for gentle and continuous stirring. Pycnometers were refilled and weights were recorded at $0.5,1.0,1.5,2,4,6,12$, $24,36,48$, and $72 \mathrm{~h}$ (Figure 1). During measurements of hydration kinetics, very small gas bubbles accumulated near the junction between the adapter and flask of the pycnometer; connecting a vacuum pump to the pycnometer for 2 min dislodged gas bubbles from the junction. Data were used to estimate the rate of hydration and water uptake or WHC using the NLIN procedures of SAS (SAS, 1998; Wattiaux, 1990). A biexponential model as described by the function below, was used to estimate hydration parameters:

$$
\mathrm{Y}_{\mathrm{t}}=\mathrm{Ae}_{\mathrm{a}}^{-\mathrm{k}}+\mathrm{Be}_{\mathrm{b}}^{-\mathrm{k}}
$$

where $Y_{t}=$ water uptake over time $(\mathrm{g} / \mathrm{g}$ of insoluble $\mathrm{DM}), \mathrm{A}$ and $\mathrm{B}$ represent pool sizes of hydration, and $k_{a}$ and $k_{b}$ represent respective fractional rates of hydration (per min). Total WHC (g/g of insoluble DM) was calculated as the sum of total solution uptake (sum of A + B) and initial moisture content of samples. A mean for hydration rate that was weighted for pool sizes from biexponential models was calculated: [ $\mathrm{A} \times$ $\left.\left.\mathrm{k}_{\mathrm{a}}\right)+\left(\mathrm{B} \times \mathrm{k}_{\mathrm{b}}\right)\right] /(\mathrm{A}+\mathrm{B})$. As mentioned before, in this study, WHC was measured using the filtration method (Giger-Reverdin, 2000; Table 1) and nonlinear curve fitting method (Wattiaux, 1990).

\section{The Effect of Alfalfa Particle Size on Animal Performance}

Animals and diets. This experiment was carried out at the dairy barn of Ferdowsi University, Mashhad, Iran. Nine multiparous midlactation Holstein dairy cows (BW $=618 \pm 17 \mathrm{~kg} ; \mathrm{DIM}=81.1 \pm 15.2$ ) were allotted to 3 replicates of a $3 \times 3$ Latin square design. The experiment consisted of 3 replicate 25 -d periods (adaptation, $14 \mathrm{~d}$; sample collection, $8 \mathrm{~d}$; and measurement of total chewing activity, 3 d). Diets had a 40:60 


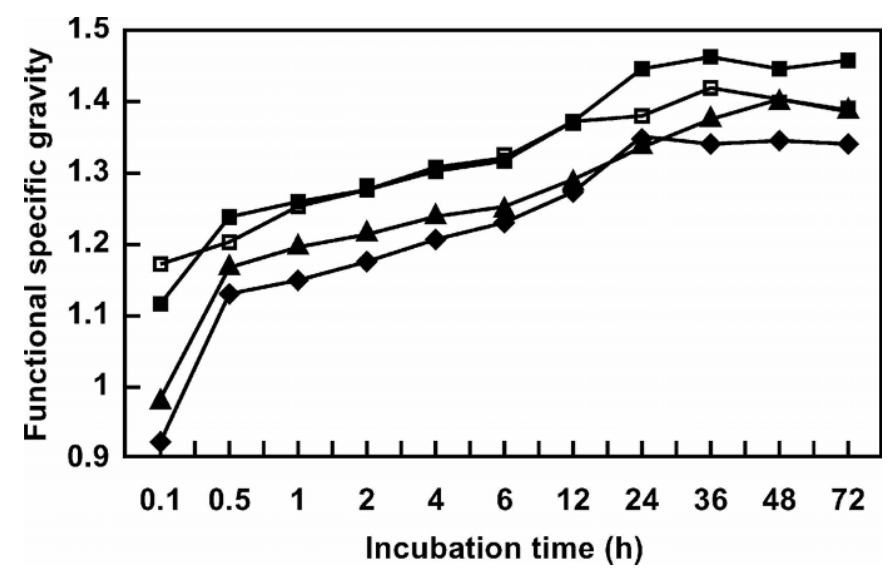

Figure 1. Functional specific gravity (FSG) of long ( ), medium

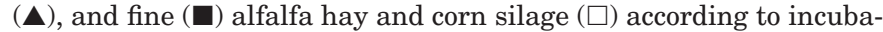
tion time $(\mathrm{h})$ measured by pycnometer. Initial $(0.1 \mathrm{~h})$ and final FSG increased when particle size decreased. Corn silage had an initial FSG higher than the 3 sizes of alfalfa. However, the final FSG of fine alfalfa was higher than long and medium alfalfa and corn silage.

forage: concentrate ratio and contained $20,20,35,7$, $7.5,10,0.3,0.1$, and $0.1 \%$ (\% of DM) of alfalfa, corn silage, barley, soybean meal, beet pulp, wheat bran, dicalcium phosphate, vitamin premix, and salt, respectively. Water and mineralized salt stone were available for cows for the duration of the experiment. Diets were formulated using the NRC system (2001) to supply adequate $\mathrm{NE}_{\mathrm{L}}$ and protein for a $615-\mathrm{kg}$ cow producing $30 \mathrm{~kg} / \mathrm{d}$ of milk, with $3.2 \%$ fat and $3.5 \% \mathrm{CP}$. Diets had similar chemical composition (Table 1), but varied in particle size distribution or the geometric mean (GM) of particles. In this study, effects of 3 TMR consisting of 3 sizes of alfalfa (long, medium, and fine) treatments were evaluated (Table 1). Three sizes of alfalfa were prepared as outlined above. Cows were housed in tie-stalls and fed ad libitum, twice daily at 0900 and $2100 \mathrm{~h}$, allowing for at least $10 \%$ orts (asfed basis).

Particle length and effectiveness fiber. Feed particle size was determined by dry sieving. The ASAE (2002, Table 1), original (Lammers et al., 1996), and new (Kononoff, 2002) PSPS sieves were used for measuring particle size distribution. The GM and the standard deviation of GM were calculated according to ASAE S424.1 (2002; Table 1). The NDF content of all materials retained on PSPS sieves was measured (Van Soest et al., 1991). Using 3 systems, the pef of forages and TMR were determined. According to Mertens (1997), the pef was determined based on proportion of DM retained on the $1.18-\mathrm{mm}$ sieve $\left(\right.$ pef $_{>1.18}$ ). Using the PSPS, the pef values were determined as the proportion of DM retained on 2 and 3 sieves of the original

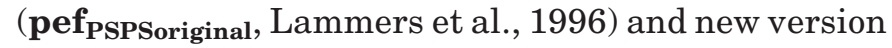

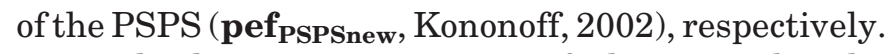
By multiplying NDF content of the TMR by the pef $_{>1.18}$, the peNDF $>1.18$ of the TMR was calculated (Table 2). The peNDF PSPSoriginal $_{\text {and }}$ peNDF ${ }_{\text {PSPSnew }}$ were calculated by multiplying the NDF content of each portion on each sieve on pef $f_{\text {PSPSoriginal }}$ and pef $f_{\text {PSPSnew }}$, respectively (Table 2 ).

Body weight, intake, and digestibility. The BW of cows was measured weekly (Table 2). The DMI was measured daily for all cows (Table 2). Daily samples of forage, TMR, and orts were collected, dried at $55^{\circ} \mathrm{C}$, ground through a Wiley mill (1-mm screen), and composited by animal within a period. Total feces were collected from all cows for $5 \mathrm{~d}$ (d 14 to 20). Feces were dried at $55^{\circ} \mathrm{C}$, and ground through a Wiley mill (1-mm screen). Feed, feces, and orts were analyzed for DM, $\mathrm{OM}$, Kjeldahl N, ether extract, ash at $605^{\circ} \mathrm{C}$ (AOAC, 2002), NDF, and ADF (Van Soest et al., 1991). Nonfiber carbohydrate was calculated as $100-(\% \mathrm{CP}+\% \mathrm{NDF}$ $+\%$ ash $+\%$ ether extract) (NRC, 2001; Table 1). Using the chemical components of TMR and feces, intake and digestibility of nutrients were calculated (Table 2). Intake of peNDF $>1.18$, peNDF $\mathrm{PSPSoriginal}_{\text {, and peNDF- }}$ PSPSnew were calculated as peNDF of each system times the average DMI of treatments (Table 2).

Ruminal characteristics. On d 22 of each period, ruminal fluid samples $(50 \mathrm{~mL})$ were taken with a stomach tube $3 \mathrm{~h}$ after feeding. Ruminal $\mathrm{pH}$ measurements were made immediately using a pH meter (Fisher Scientific, AR50), and samples were frozen at $-20^{\circ} \mathrm{C}$. The concentration of $\mathrm{N}-\mathrm{NH}_{3}$ was measured with a Kjeltec Auto Analyzer (Model 1030, Tecator Co., Sweden) according to AOAC (2002). Ruminal fluid was acidified with $2.5 \mathrm{~mL}$ of $6 \mathrm{~N} \mathrm{HCl}$ and frozen for further analysis of VFA. Ruminal fluid was centrifuged at $25,000 \times g$ for 20 min before measurement of VFA by gas chromatography (Merchen et al., 1986).

Chromium-mordanted alfalfa NDF was prepared as described by Uden et al. (1980) and used as a single dose marker for solid passage rate measurement. Chromium-mordanted fiber was prepared by mordanting alfalfa NDF ground through a $5-\mathrm{mm}$ screen using a Wiley mill. On d 15 of each experiment, markers were fed to all cows at the morning feeding time. Fecal grab samples were taken at $0,6,10,12,14,18$, $22,26,30,36,42,48,54,60,72,84,96,120$, and 144 $\mathrm{h}$ after dosing to determine the passage rate, RMRT, total mean retention time (TMRT), and time delay (transit time) of the marker (Table 3). Samples were dry-ashed, and fecal $\mathrm{Cr}$ concentrations were determined by direct current plasma emission spectroscopy (AOAC, 2002).

Chewing behavior. Eating and ruminating activities were monitored visually for cows in the treatments 
Table 2. Body weight, intake, and digestibility of nutrients of cows fed 3 total mixed rations containing 3 sizes of alfalfa.

\begin{tabular}{|c|c|c|c|c|c|}
\hline & \multicolumn{3}{|c|}{ Total mixed ration containing alfalfa } & \multirow[b]{2}{*}{ SEM } & \multirow[b]{2}{*}{$P$} \\
\hline & Long & Medium & Fine & & \\
\hline $\mathrm{BW}(\mathrm{kg})$ & 616.5 & 620.2 & 622.5 & 9.12 & NS \\
\hline BW changes $(\mathrm{kg})$ & $+20.5^{\mathrm{b}}$ & $+25.1^{\mathrm{ab}}$ & $+28.0^{\mathrm{a}}$ & 1.57 & $*$ \\
\hline \multicolumn{6}{|l|}{ Intake $(\mathrm{kg} / \mathrm{d})$} \\
\hline DM & $21.26^{\mathrm{b}}$ & $22.64^{\mathrm{b}}$ & $24.81^{\mathrm{a}}$ & 0.37 & $* * *$ \\
\hline $\mathrm{OM}$ & $19.29^{\mathrm{b}}$ & $20.55^{\mathrm{b}}$ & $22.81^{\mathrm{a}}$ & 0.34 & $* * *$ \\
\hline NDF & $7.02^{\mathrm{b}}$ & $7.47^{\mathrm{b}}$ & $8.19^{\mathrm{a}}$ & 0.12 & $* * *$ \\
\hline peNDF $_{>118}{ }^{1}$ & $4.98^{\mathrm{a}}$ & $4.63^{\mathrm{b}}$ & $3.77^{\mathrm{c}}$ & 0.07 & $* * *$ \\
\hline peNDF $_{\text {PSPSoriginal }}^{2}$ & $2.38^{\mathrm{a}}$ & $1.27^{\mathrm{b}}$ & $0.50^{\mathrm{b}}$ & 0.02 & $* * *$ \\
\hline peNDF $_{\text {PSPSnew }}$ & $5.33^{\mathrm{a}}$ & $5.12^{\mathrm{a}}$ & $4.26^{\mathrm{b}}$ & 0.07 & $* * *$ \\
\hline $\mathrm{ADF}$ & $4.79^{\mathrm{b}}$ & $5.10^{\mathrm{b}}$ & $5.58^{\mathrm{a}}$ & 0.08 & $* * *$ \\
\hline $\mathrm{CP}$ & $3.61^{\mathrm{b}}$ & $3.85^{\mathrm{b}}$ & $4.22^{\mathrm{a}}$ & 0.01 & $* * *$ \\
\hline NFC & $9.11^{\mathrm{b}}$ & $9.61^{\mathrm{b}}$ & $10.65^{\mathrm{a}}$ & 0.02 & $* * *$ \\
\hline Ether extract & $0.90^{\mathrm{b}}$ & $0.96^{\mathrm{b}}$ & $1.05^{\mathrm{a}}$ & 0.02 & $* * *$ \\
\hline Ash & $1.97^{\mathrm{b}}$ & $2.09^{b}$ & $2.29^{\mathrm{a}}$ & 0.03 & $* * *$ \\
\hline \multicolumn{6}{|c|}{ peNDF intake (\% of DMI) } \\
\hline $\mathrm{peNDF}_{>1.18}$ & $23.43^{\mathrm{a}}$ & $20.45^{\mathrm{b}}$ & $15.18^{\mathrm{c}}$ & 0.003 & $* * *$ \\
\hline peNDF ${ }_{\text {PSPSoriginal }}$ & $11.22^{\mathrm{a}}$ & $5.61^{\mathrm{b}}$ & $1.99^{\mathrm{c}}$ & 0.005 & $* * *$ \\
\hline peNDF ${ }_{\text {PSPSnew }}$ & $25.08^{\mathrm{a}}$ & $22.60^{\mathrm{b}}$ & $17.17^{\mathrm{c}}$ & 0.003 & $* * *$ \\
\hline \multicolumn{6}{|l|}{ Digestibility (\%) } \\
\hline DM & 69.99 & 71.12 & 71.30 & 0.24 & NS \\
\hline $\mathrm{OM}$ & 72.10 & 72.21 & 71.32 & 0.38 & NS \\
\hline NDF & $61.31^{\mathrm{a}}$ & $61.09^{\mathrm{a}}$ & $56.60^{\mathrm{b}}$ & 1.08 & $\dagger$ \\
\hline $\mathrm{ADF}$ & 56.56 & 54.27 & 55.30 & 0.63 & NS \\
\hline $\mathrm{CP}$ & 77.33 & 77.42 & 76.89 & 0.57 & NS \\
\hline $\mathrm{NFC}$ & 83.80 & 85.33 & 85.93 & 2.24 & NS \\
\hline Ether extract & 66.94 & 68.21 & 68.40 & 0.27 & NS \\
\hline Ash & $63.45^{\mathrm{a}}$ & $60.47^{\mathrm{b}}$ & $57.02^{\mathrm{c}}$ & 1.14 & $*$ \\
\hline
\end{tabular}

a,b,c Means within a row with different superscripts differ $(P<0.05)$.

$\dagger P=0.051$. Although means were separated using Duncan's multiple range test with an alpha level of 0.05 and $P$-value was ?0.051, but difference between treatments were significantly different.

$* P \leq 0.05 ; * * P \leq 0.01 ; * * * P \leq 0.001$.

${ }^{1}$ peNDF $_{>1.18}=$ Physically effective NDF based on DM retained on 1.18-mm sieve (Mertens, 1997).

${ }^{2}$ peNDF ${ }_{\text {PSPSoriginal }}=$ Physically effective NDF determined as the proportion of DM retained on sieves of the original version of PSPS (Lammers et al., 1996).

${ }^{3} \mathrm{peNDF}_{\mathrm{PSPSnew}}=$ Physically effective NDF determined as the proportion of DM retained on sieves of the new version of PSPS (Kononoff, 2002).

over a $24 \mathrm{~h}$ period for $3 \mathrm{~d}$ from d 23 to 25 of each experimental period (Table 4). Eating and ruminating activities were noted at 5-min intervals, and each activity was assumed to persist for the entire 5-min interval. A period of rumination was defined as at least $5 \mathrm{~min}$ of ruminating activity followed by at least 5 min without ruminating activity. Total time spent chewing was calculated as the total time spent eating and ruminating (Table 4). The average DMI in the experimental period was used to estimate time spent eating, ruminating, and total chewing activity per daily intake of DM, NDF, peNDF $_{>1.18}$, peNDF $_{\text {PSPSoriginal }}$, peNDF ${ }_{\text {PSPSnew }}, \mathrm{NFC}$, and BW (Table 4).

Milk sample and analysis. Daily milk yields were recorded throughout the experiment. On d 18 to 22 of each experimental period, milk samples were collected at each morning and evening milking. About $100 \mathrm{~mL}$ of each morning and evening milk sample was composited and analyzed for total $\mathrm{N}(\mathrm{CP})$, true protein $\mathrm{N}$, fat, noncasein $\mathrm{N}$, casein protein $\mathrm{N}, \mathrm{NPN}$, and lactose (AOAC, 2002; Table 5). Noncasein $\mathrm{N}$ was determined by Kjeldahl analysis of filtrate after precipitation with $10 \%$ acetic acid and $1 \mathrm{~N}$ sodium acetate. Casein protein $\mathrm{N}$ was calculated as the difference between total $\mathrm{N}$ and noncasein N. Nonprotein $\mathrm{N}$ was calculated as the difference between total $\mathrm{N}$ and true protein $\mathrm{N}$.

Statistical analyses. Using the PROC GLM of SAS (1998), data of hydration rate, WHC, and FSG measurements were analyzed in a completely randomized design with particle size of forages considered as treatment (Wattiaux, 1990; Table 1). Means were separated using Duncan's multiple range test with an alpha level of 0.05 .

Using the PROC MIXED procedure of SAS (1998), the experimental data were analyzed as a $3 \times 3$ replicated Latin square design by following model:

$$
\mathrm{Y}_{\mathrm{ijkln}}=\mu+\mathrm{T}_{\mathrm{i}}+\mathrm{S}_{\mathrm{j}}+\operatorname{cow}_{\mathrm{k}(\mathrm{j})}+\operatorname{period}_{\mathrm{j}(1)}+\mathrm{e}_{\mathrm{ijkln}},
$$


Table 3. Ruminal metabolites and digestion kinetics of cows fed 3 total mixed rations including 3 sizes of alfalfa.

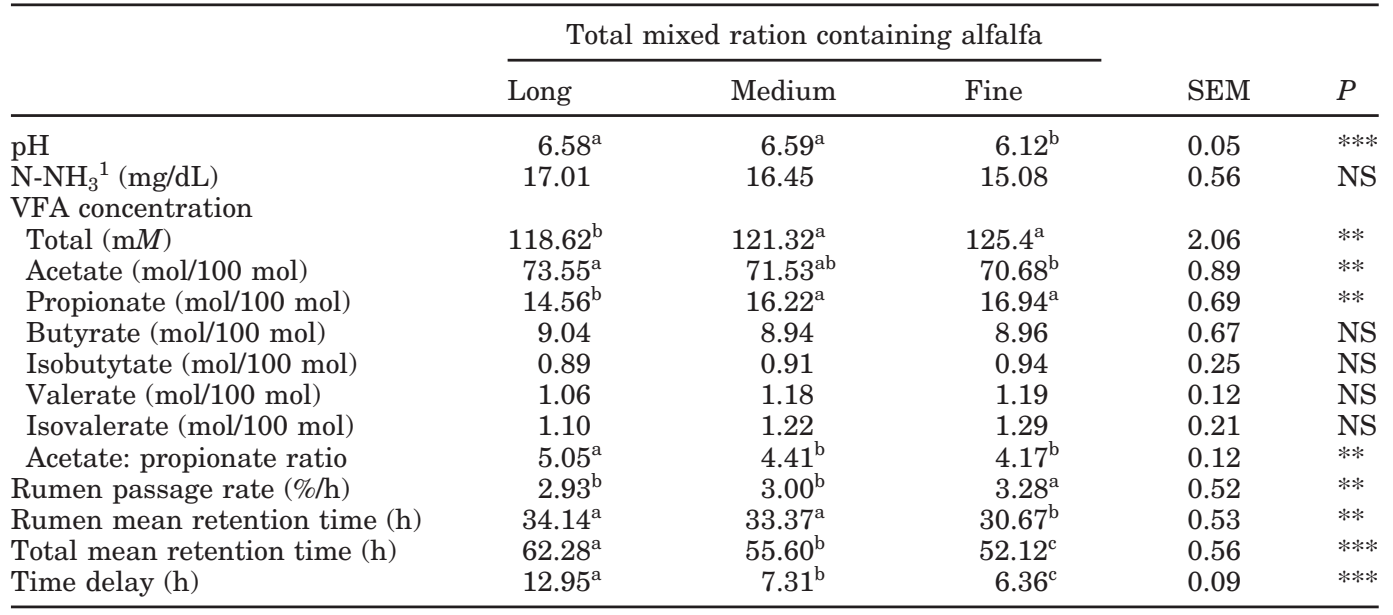

a,b,c Means within a row with different superscripts differ $(P<0.05)$.

$* * P \leq 0.01 ; * * * P \leq 0.001$.

${ }^{1} \mathrm{~N}-\mathrm{NH}_{3}=\mathrm{NH}_{3}$ concentration.

where $\mathrm{Y}_{\mathrm{ijkln}}$ was the dependent variable, $\mu$ is the overall mean, $\mathrm{T}_{\mathrm{i}}$ is the random effect of the long, medium, and fine alfalfa treatments $(i=1,2$, and 3$) ; S_{j}$ is the random effect of $j$ th square $(j=1,2$, and 3$), \operatorname{cow}_{k}(j)$ is the cow effect inside of each square, period $d_{j(1)}$ is the effect of each period inside each square, and $e_{i j k l n}$ is experimental error.

The particle size data were analyzed as a completely randomized design with model effects of forage and 2 methods of particle size measurement using the REML variance component and PROC MIXED procedure of SAS (1998, Table 1). Means separation was determined using the PDIFF procedure and significance was declared at $P<0.05$.

Fecal Cr excretion curves were fitted to the double compartment model represented by 2 exponential constants and a time delay (Grovum and Williams, 1973):

$$
\begin{gathered}
\mathrm{Y}=\mathrm{Ae}^{-\mathrm{k}_{1}(\mathrm{t}-\mathrm{TT})}+\mathrm{Ae}_{2}^{-\mathrm{k}_{2}(\mathrm{t}-\mathrm{TT})}, \mathrm{k}_{1}=\mathrm{k}_{2} \text { for } \mathrm{t} \geq \mathrm{T}, \\
\mathrm{Y}=0 \text { for } \mathrm{t}=\mathrm{TT},
\end{gathered}
$$

where $\mathrm{Y}=$ marker concentration $(\mathrm{ppm}), \mathrm{A}=$ scale parameter, $\mathrm{k}_{1}=$ ruminal rate of passage $(\% / \mathrm{h}), \mathrm{k}_{2}=$ lower digestive tract rate of passage $(\% / \mathrm{h}), \mathrm{t}=$ sampling time post dosing (h), and TT $=$ transit time or time delay of marker. The TMRT was calculated as the sum of RMRT $\left(1 / k_{1}\right)$ and, in the lower digestive tract, mean retention time $\left(1 / \mathrm{k}_{2}\right)$ plus the transit time (TT). Data were estimated by NLIN regression using the PROC NLIN (iterative Marquardt method) procedure of SAS (1998, Table 4). The estimated parameters were analyzed according to above experimental design. Analysis of correlation between NDF intake $(\mathrm{kg})$, milk fat
(\%), rumen $\mathrm{pH}$, total chewing activity (min/d), peNDF, 1.18 intake (kg), FSG of TMR, FSG of forage, and RMRT was carried out using the PROC CORR of SAS (1998, Table 6).

\section{RESULTS AND DISCUSSION}

\section{Kinetics of Hydration Measurement}

Chemical composition of 3 sizes of alfalfa, and consequently TMR, was not affected by reduction of particle size (Table 1). Nevertheless, in both alfalfa and TMR, reduction of particle size significantly influenced physical characteristics. Reduction of particle size increased bulk density $(P<0.0001)$ and FSG $(P=0.001)$, but decreased WHC $(P<0.0001)$ of alfalfa (Table 1$)$. In addition, reduction of particle size increased bulk density $(P<0.0001)$ and FSG $(P=0.0006)$, but decreased WHC $(P<0.0001)$ of TMR. The values of WHC obtained in filtration are presented in Table 1 . The WHC values that were obtained using the nonlinear curve fitting method were $1.403,1.458,1.514$, and 1.448 (g/g insoluble DM) in long, medium, and fine alfalfa, and corn silage, respectively. The values obtained in filtration were significantly higher than by the other method. The results were similar to GigerReverdin (2000) and Wattiaux (1990). However, the NLIN curve fitting had a lower estimation of WHC (Wattiaux, 1990). As particle size decreased, the amount of insoluble DM decreased (Table 1). Regardless of the size, the value of insoluble DM in corn silage was lower than in alfalfa; however, corn silage had higher WHC than alfalfa (Table 1). In alfalfa and TMR, 
Table 4. Chewing activity of cows fed 3 total mixed rations including 3 sizes of alfalfa.

\begin{tabular}{|c|c|c|c|c|c|}
\hline \multirow[b]{2}{*}{ Activity } & \multicolumn{3}{|c|}{ Total mixed ration containing alfalfa } & \multirow[b]{2}{*}{ SEM } & \multirow[b]{2}{*}{$P$} \\
\hline & Long & Medium & Fine & & \\
\hline Eating $(\mathrm{min} / \mathrm{d})$ & $257.8^{\mathrm{a}}$ & $232.8^{\mathrm{ab}}$ & $209.4^{\mathrm{b}}$ & 10.27 & $*$ \\
\hline Rumination $(\mathrm{min} / \mathrm{d})$ & $338.9^{\mathrm{a}}$ & $286.1^{\mathrm{b}}$ & $236.1^{\mathrm{c}}$ & 7.80 & $* * *$ \\
\hline Total chewing activity $(\mathrm{min} / \mathrm{d})$ & $596.7^{\mathrm{a}}$ & $518.9^{\mathrm{b}}$ & $445.5^{\mathrm{c}}$ & 10.48 & $* * *$ \\
\hline \multicolumn{6}{|c|}{ Chewing behavior per different nutrients $(\mathrm{min} / \mathrm{kg})$} \\
\hline \multicolumn{6}{|c|}{ Eating } \\
\hline DMI & $12.2^{\mathrm{a}}$ & $10.3^{\mathrm{b}}$ & $8.5^{\mathrm{c}}$ & 0.55 & $* *$ \\
\hline $\mathrm{NDF}$ & $36.8^{\mathrm{a}}$ & $31.2^{\mathrm{b}}$ & $25.6^{\mathrm{c}}$ & 1.66 & $* *$ \\
\hline $\mathrm{peNDF}_{>1.18}{ }^{1}$ & 51.9 & 50.3 & 55.5 & 2.43 & NS \\
\hline peNDF $_{\text {PSPSoriginal }}^{2}$ & $108.3^{\mathrm{c}}$ & $183.3^{\mathrm{b}}$ & $418.9^{\mathrm{a}}$ & 14.25 & $* *$ \\
\hline peNDF $_{\text {PSPSnew }}{ }^{3}$ & 48.4 & 45.5 & 49.2 & 3.21 & NS \\
\hline $\mathrm{ADF}$ & $54.1^{\mathrm{a}}$ & $45.7^{\mathrm{b}}$ & $37.6^{\mathrm{c}}$ & 1.27 & ** \\
\hline $\mathrm{NFC}$ & $28.4^{\mathrm{a}}$ & $23.9^{\mathrm{b}}$ & $19.7^{\mathrm{c}}$ & 1.15 & ** \\
\hline BW & $0.42^{\mathrm{a}}$ & $0.39^{\mathrm{b}}$ & $0.34^{\mathrm{c}}$ & 0.02 & $* *$ \\
\hline \multicolumn{6}{|l|}{ Rumination } \\
\hline DMI & $15.9^{\mathrm{a}}$ & $12.6^{\mathrm{ab}}$ & $9.5^{\mathrm{b}}$ & 0.35 & $* * *$ \\
\hline NDF & $48.3^{\mathrm{a}}$ & $38.3^{\mathrm{ab}}$ & $28.9^{\mathrm{b}}$ & 1.06 & $* * *$ \\
\hline peNDF $_{>1.18}$ & $68.0^{\mathrm{a}}$ & $61.8^{\mathrm{b}}$ & $62.6^{\mathrm{b}}$ & 1.90 & $* *$ \\
\hline peNDF ${ }_{\text {PSPSoriginal }}$ & $142.3^{\mathrm{c}}$ & $225.3^{\mathrm{b}}$ & $480.9^{\mathrm{a}}$ & 32.13 & $* *$ \\
\hline peNDF ${ }_{\text {PSPSnew }}$ & $63.6^{\mathrm{a}}$ & $55.9^{\mathrm{b}}$ & $55.5^{\mathrm{b}}$ & 1.61 & $* *$ \\
\hline $\mathrm{ADF}$ & $105.7^{\mathrm{a}}$ & $104.8^{\mathrm{a}}$ & $92.0^{\mathrm{b}}$ & 1.57 & **** \\
\hline $\mathrm{NFC}$ & $37.2^{\mathrm{a}}$ & $29.5^{\mathrm{b}}$ & $22.2^{\mathrm{c}}$ & 0.81 & $* * *$ \\
\hline BW & $0.55^{\mathrm{a}}$ & $0.46^{\mathrm{b}}$ & $0.38^{\mathrm{c}}$ & 0.02 & $* * *$ \\
\hline \multicolumn{6}{|l|}{ Total chewing activity } \\
\hline DMI & $28.1^{\mathrm{a}}$ & $22.9^{\mathrm{ab}}$ & $17.9^{\mathrm{b}}$ & 0.67 & $* * *$ \\
\hline $\mathrm{NDF}$ & $85.2^{\mathrm{a}}$ & $69.9^{\mathrm{ab}}$ & $54.5^{\mathrm{b}}$ & 2.03 & $* * *$ \\
\hline peNDF $_{>1.18}$ & $119.8^{\mathrm{a}}$ & $112.1^{\mathrm{b}}$ & $118.2^{\mathrm{a}}$ & 3.29 & $* * *$ \\
\hline peNDF $F_{\text {PSPSoriginal }}$ & $249.9^{\mathrm{c}}$ & $408.6^{\mathrm{b}}$ & $925.9^{\mathrm{a}}$ & 24.24 & $* * *$ \\
\hline peNDF $_{\text {PSPSnew }}$ & $112.1^{\mathrm{a}}$ & $104.8^{\mathrm{ab}}$ & $101.5^{\mathrm{b}}$ & 3.46 & $*$ \\
\hline $\mathrm{ADF}$ & $125.0^{\mathrm{a}}$ & $101.9^{\mathrm{ab}}$ & $74.9^{\mathrm{b}}$ & 2.96 & **** \\
\hline NFC & $65.6^{\mathrm{a}}$ & $53.6^{\mathrm{ab}}$ & $41.9^{\mathrm{b}}$ & 1.55 & $* * *$ \\
\hline BW & $0.97^{\mathrm{a}}$ & $0.84^{\mathrm{b}}$ & $0.72^{\mathrm{c}}$ & 0.02 & $* * *$ \\
\hline
\end{tabular}

a,b,c Means within a row with different superscripts differ $(P<0.05)$.

$* P \leq 0.05 ; * * P \leq 0.01 ; * * * P \leq 0.001$.

${ }^{1}$ peNDF $_{>1.18}=$ Physically effective NDF based on DM retained on 1.18-mm sieve (Mertens, 1997).

${ }^{2}$ peNDF PSPSoriginal $_{\text {P }}$ Physically effective NDF determined as the proportion of DM retained on sieves of the original version of PSPS (Lammers et al., 1996).

${ }^{3}$ peNDF $_{\text {PSPSnew }}=$ Physically effective NDF determined as the proportion of DM retained on sieves of the new version of PSPS (Kononoff, 2002).

reduction of particle size decreased the rate of hydration $(P=0.039$ and $P=0.009$, respectively). Rate of hydration was $0.098,0.108,0.121$, and 0.094 in long, medium, and fine alfalfa, and corn silage, respectively. Rate of hydration increased as alfalfa particle size decreased. Regardless of the size, corn silage had a lower hydration rate than alfalfa hay.

Reduction of particle size increased FSG of alfalfa particles $(P=0.0006$; Table 1 and Figure 1$)$. In long, medium, and fine alfalfa and corn silage, FSG was $1.181,1.262,1.431$, and 1.311 , respectively. In addition, in long, medium, and fine alfalfa treatments, FSG were $1.391,1.467$, and 1.557 , respectively (Table 1 ). Initial and final FSG increased when particle size decreased (Figure 1). Corn silage had an initial FSG higher than the 3 sizes of alfalfa. However, the final FSG of fine alfalfa was higher than long and medium alfalfa, and corn silage (Figure 1). The results were similar to Hooper and Welch (1985), Wattiaux (1990), and Siciliano-Jones and Murphy (1991).

In ruminants, the voluntary DMI and ruminal filling is related to the bulk density of forages (Wattiaux, 1990), but RMRT and passage rate are related to FSG of feeds (Kaske and Engelhardt, 1990; Wattiaux, 1990; Siciliano-Jones and Murphy, 1991). In this study, the GM of particle size was selected at 3 levels, including higher than, equal to, and lower than the threshold size (Poppi et al., 1980). At this threshold of size, FSG is the most important factor for estimating the effectiveness of fiber. For stimulating chewing activity, particles must be retained in the rumen. According to Kaske and Engelhardt (1990), the extent of FSG is a better indicator of RMRT than particle size. When particles reach a threshold size and FSG, they must pass the rumen. However, large particles always need more time than the small particles to be escapable 
Table 5. Milk production and composition of cows fed 3 total mixed rations including 3 sizes of alfalfa.

\begin{tabular}{|c|c|c|c|c|c|}
\hline & \multicolumn{3}{|c|}{ Total mixed ration containing alfalfa } & \multirow[b]{2}{*}{ SEM } & \multirow[b]{2}{*}{$P$} \\
\hline & Long & Medium & Fine & & \\
\hline \multicolumn{6}{|c|}{ Milk and its composition production (kg/d) } \\
\hline Milk & 30.25 & 30.94 & 31.36 & 0.38 & NS \\
\hline $4 \% \mathrm{FCM}$ & 26.71 & 26.11 & 26.12 & 0.34 & NS \\
\hline Fat & $0.97^{\mathrm{a}}$ & $0.96^{\mathrm{a}}$ & $0.90^{\mathrm{b}}$ & 0.01 & * \\
\hline Protein & $1.08^{\mathrm{b}}$ & $1.10^{\mathrm{b}}$ & $1.18^{\mathrm{a}}$ & 0.02 & $*$ \\
\hline Lactose & 1.41 & 1.42 & 1.47 & 0.02 & NS \\
\hline Casein & $0.70^{\mathrm{b}}$ & $0.71^{\mathrm{b}}$ & $0.77^{\mathrm{a}}$ & 0.01 & ** \\
\hline Noncasein protein & $0.04^{\mathrm{b}}$ & $0.05^{\mathrm{b}}$ & $0.06^{\mathrm{a}}$ & 0.002 & $* *$ \\
\hline True protein & $0.79^{\mathrm{b}}$ & $0.79^{\mathrm{b}}$ & $0.87^{\mathrm{a}}$ & 0.01 & $* *$ \\
\hline NPN & $0.34^{\mathrm{b}}$ & $0.34^{\mathrm{b}}$ & $0.37^{\mathrm{a}}$ & 0.01 & $* *$ \\
\hline Total solid & 3.47 & 3.42 & 3.57 & 0.06 & NS \\
\hline \multicolumn{6}{|l|}{ Composition (\%) } \\
\hline Fat & $3.21^{\mathrm{a}}$ & $3.15^{\mathrm{a}}$ & $2.88^{\mathrm{b}}$ & 0.03 & $* * *$ \\
\hline Protein & $3.57^{\mathrm{b}}$ & $3.61^{\mathrm{b}}$ & $3.76^{\mathrm{a}}$ & 0.03 & $* *$ \\
\hline Lactose & 4.69 & 4.67 & 4.69 & 0.05 & NS \\
\hline Casein & $2.47^{\mathrm{b}}$ & $2.49^{b}$ & $2.59^{\mathrm{a}}$ & 0.02 & $* *$ \\
\hline Noncasein protein & $0.12^{\mathrm{b}}$ & $0.15^{\mathrm{b}}$ & $0.16^{\mathrm{a}}$ & 0.001 & $* *$ \\
\hline True protein & $2.61^{b}$ & $2.64^{\mathrm{b}}$ & $2.75^{\mathrm{b}}$ & 0.02 & $* *$ \\
\hline NPN & $0.96^{\mathrm{b}}$ & $0.97^{\mathrm{b}}$ & $1.01^{\mathrm{a}}$ & 0.01 & $* *$ \\
\hline Total solid & 11.48 & 11.43 & 11.33 & 0.08 & NS \\
\hline
\end{tabular}

${ }^{\mathrm{a}, \mathrm{b}}$ Means within a row with different superscripts differ $(P<0.05)$.

$* P \leq 0.05 ; * * P \leq 0.01 ; * * P \leq 0.001$.

(Kaske and Engehardt, 1990). According to FSG, the long, medium, and fine alfalfa particles were escapable from the rumen after 4,1 , and $0.5 \mathrm{~h}$ incubation, respectively (Figure 1).

\section{The Effect of Alfalfa Particle Size on Animal Performance}

Particle length and effectiveness fiber. Particle size distribution of TMR reflected the alfalfa particle size included in the treatments. Using the original PSPS, the proportion of material retained on the 19$\mathrm{mm}$ sieve was $14.68,5.54$, and 0.91 ; on the 8 -mm sieve, $19.11,11.68$, and 4.98; and on the pan, 66.21, 82.98, and $94.11 \%$ in the long, medium, and fine alfalfa treat- ments, respectively. Using the new PSPS, the proportion of material retained on the $19-\mathrm{mm}$ sieve was $14.53,5.65$, and 0.99 ; on the $8-\mathrm{mm}$ sieve was 18.56 , 11.54 , and 5.3; on the 1.18 -mm sieve was $42.56,51.26$, and 45.65 ; and on the pan was $24.36,31.55$, and 48.00 , respectively, for the long, medium, and fine alfalfa treatments.

Using the ASAE sieves, milling of alfalfa resulted in less material being retained on the $19-\mathrm{mm}$ sieve, but increased $(P<0.0001)$ the proportion of particles in the pan (Table 1). In both alfalfa and TMR, proportion of particles on 1.18-mm sieves and pan increased with decreasing particle size $(P<0.0001$; Table 1$)$.

Using the original PSPS, the GM of long, medium, and fine alfalfa and long, medium, and fine alfalfa

Table 6. Correlation coefficients (\%, above diagonal) between animal response variable and their $P$-values (below diagonal) in experimental cows fed 3 total mixed rations including 3 sizes of alfalfa.

\begin{tabular}{|c|c|c|c|c|c|c|c|c|}
\hline Variable $^{1}$ & $\begin{array}{l}\text { NDF } \\
\text { intake }\end{array}$ & $\begin{array}{l}\text { Milk } \\
\text { fat }\end{array}$ & $\begin{array}{l}\text { Rumen } \\
\mathrm{pH}\end{array}$ & $\begin{array}{l}\text { Total chewing } \\
\text { activity }\end{array}$ & $\begin{array}{l}\text { peNDF }_{>1.18} \\
\text { intake }\end{array}$ & $\begin{array}{l}\text { FSG of } \\
\text { TMR }\end{array}$ & $\begin{array}{l}\text { FSG of } \\
\text { forage }\end{array}$ & RMRT \\
\hline NDF intake & & -0.69 & -0.70 & -0.76 & -0.68 & 0.62 & 0.99 & -0.49 \\
\hline Milk fat & $* * *$ & & 0.60 & 0.78 & 0.86 & -0.63 & -0.69 & 0.59 \\
\hline Rumen pH & $* * *$ & $* *$ & & 0.66 & 0.71 & -0.63 & -0.70 & 0.53 \\
\hline Total chewing activity & $* * *$ & $* * *$ & $* *$ & & 0.77 & -0.68 & -0.76 & 0.43 \\
\hline peNDF $_{>1.18}$ intake & $* * *$ & $* * *$ & $* * *$ & $* * *$ & & -0.85 & -0.68 & 0.68 \\
\hline FSG of TMR & $* *$ & $* *$ & $* *$ & $* *$ & $* * *$ & & 0.62 & -0.73 \\
\hline FSG of forage & $* * *$ & $* * *$ & $* * *$ & $* * *$ & $* * *$ & $* *$ & & -0.64 \\
\hline RMRT & $* *$ & $* *$ & $* *$ & $* *$ & $* * *$ & $* * *$ & $* * *$ & \\
\hline
\end{tabular}

$* * P \leq 0.01 ; * * * P \leq 0.001$.

${ }^{1} \mathrm{peNDF}_{>1.18}=$ Physically effective NDF intake $(\mathrm{kg})$ calculated as DMI times pef times NDF content of rations. Physically effective factor was based on DM retained on 1.18-mm sieve (Mertens, 1997); FSG = functional specific gravity; RMRT = ruminal mean retention time. 
treatments were $6.58,2.68$, and $0.83 \mathrm{~mm}$; and 2.35 , 1.39 , and $0.98 \mathrm{~mm}$, respectively. Using the new PSPS, the GM of long, medium, and fine alfalfa and long, medium, and fine alfalfa treatments were 10.29, 5.01, and $1.54 \mathrm{~mm}$; and $4.34,2.97$, and $1.96 \mathrm{~mm}$, respectively. In addition, the GM of alfalfa and TMR were significantly decreased in the medium and fine alfalfa treatments. The amount of reduction of alfalfa GM was 60 and $87 \%$ with original PSPS; 51 and $85 \%$ with new PSPS sieves, and about 48.5 and $85.5 \%$ with ASAE sieves in the medium and fine alfalfa treatments, respectively, compared with the GM in the long alfalfa treatment (Table 1). Also, the amount of reduction of GM of TMR were 41 and $58 \%$ with original PSPS; 31.5 and $55 \%$ with new PSPS sieves, and about 26 and $50 \%$ with ASAE sieves in the medium and fine alfalfa treatments, respectively, compared with the GM in the long alfalfa treatment. As the GM of alfalfa and TMR decreased, the size of the standard deviation of GM of particle size decreased. These results are similar to those of Kononoff (2002).

The values of pef $_{>1.18}$, pef $f_{\text {PSPSoriginal, }}$, and pef $f_{\text {PSPSnew }}$ of long, medium, and fine alfalfa and long, medium, and fine alfalfa treatments were different within systems (Table 1). Regardless of the methods and evaluation system, as the GM of alfalfa decreased, the values of pef decreased, and these values reflected the alfalfa particle size. Using the original PSPS, pef values were the lowest estimation of pef of alfalfa and TMR compared to another pef system. The values of pef $_{>1.18}$ and pef $_{\text {PSPSnew }}$ were very close (Table 1 ).

According to Kononoff (2002), the range of TMR particle size distributions used in the current experiment were comparable to those of commercial dairy farms. Although few experiments have been conducted to investigate the effects of feeding rations of different peNDF on total chewing activity and rumen $\mathrm{pH}$, Mertens (1997) suggested that a minimum of $21 \%$ peNDF was required to adequately stimulate chewing activity and maintain an average rumen $\mathrm{pH}$ of greater than 6.0.

Body weight, intake, and digestibility. The cows had similar initial BW at the start of experiment, but reduction of particle size increased the BW of cows over the experiment (Table 2). The amount of BW gain was higher in medium and fine alfalfa treatments compared with long alfalfa treatment $(P=0.019$; Table 2$)$. In the current study, midlactation dairy cows were allotted and energy status was improved as feeding diets of reduced particle size tended to increase BW $(P=0.002$; Table 2).

As particle size decreased, there was an increase in $\mathrm{DMI}$ and consequently in the daily intake of OM, NDF, $\mathrm{ADF}, \mathrm{CP}, \mathrm{NFC}$, ether extract, and forage in the me- dium and fine alfalfa treatments compared with the long alfalfa treatment (Table 2; $P=0.0001$ ). Feeds of longer particle size usually result in greater fill because of a slower rate of passage, limiting DMI through distension. During this time, it has been suggested that reducing diet particle size could positively affect DMI because the density of particles increases (Allen, 2000). Shaver et al. (1988) and Beauchemin et al. (1997) found that when poor quality, high fiber diets were fed, reducing the forage particle size significantly increased DMI. Forage particle size has less impact on intake when well-balanced rations are fed to lactating cows (Beauchemin et al., 1997). Voluntary DMI and nutrient supply can be constrained by rumen fill and clearance of digesta from the rumen. Reducing particle size decreases the filling effects of forage and increases ruminal passage rate (Allen, 2000). Hence, forages that occupy larger volumes per unit of DM weight (have lower bulk density) should have a greater ruminal filling effect than more dense forages (Wattiaux, 1990). As mentioned before, the DMI is related to bulk density of feeds, but RMRT and passage rate are related to FSG. The results of our study showed that reduction of particle size significantly increased the bulk density and FSG of alfalfa and TMR (Table 1), and increased ruminal particulate passage rate due to increased DMI (Table 2).

Regardless of the effective system, as particle size decreased, daily intake of NDF increased, but the proportional peNDF intake (\% of DMI; $P<0.0001)$ and daily intake of peNDF $(\mathrm{kg})$ decreased $(P<0.0001$; Table 2); this could be result of increased DMI.

Reduction of particle size had no effect on digestibility of DM, OM, ADF, NFC, CP, or ether extract but reduced digestibility of NDF $(P=0.051)$ and ash $(P=$ 0.039 ; Table 2). A small (nonsignificant) increase in digestibility of DM, NFC, and ether extract was the result of increased surface area available for microbial attack, ultimately resulting in a more rapid rate of ruminal fermentation and increased intake (Allen and Mertens, 1988; Mertens, 1997). Although depressed fiber digestibility has been observed when forage particle size is reduced, this is usually observed when a severe elevation in the rate of passage is much greater than changes in rate of digestibility. The effect of particle size reduction on total tract NDF digestibility can be explained by a reduction in ruminal digestion. The extent of ruminal digestion depends on the intensity of fermentation and the RMRT of particulate matter. Particle size reduction decreased RMRT $(P=0.002)$ but increased passage rate $(P=0.002$; Table 3$)$. According to Shaver et al. (1988), decreased ruminal $\mathrm{pH}$, increased intake, and increased passage rate due to reduction of alfalfa particle size is predicted to depress 
digestibility in slowly digested material such as NDF, especially in the fine alfalfa treatment.

Ruminal characteristics. Reducing forage particle size decreased ruminal $\mathrm{pH}$ (Table $3 ; P=0.0003$ ). The lower ruminal $\mathrm{pH}$ corresponded to higher concentration of propionate (and thus a lower acetate: propionate ratio) (Table 3), and lower total chewing activity or rumination time (Table 4) in the medium and fine alfalfa treatments compared with the long alfalfa treatment. The amount of saliva secretion is the most important factor influencing rumen $\mathrm{pH}$. When animals are fed adequate amounts of long forage, ruminal $\mathrm{pH}$ is buffered due to increased saliva flow. However, reduction of particle size reduced total chewing activity and saliva flow in ruminants (Mertens, 1997, 2000). Grant et al. (1990) found that lack of effective fiber is the primary cause of borderline acidosis and milk fat depression. They harvested alfalfa silage at 3 different cut lengths; although increasing chop length increased milk fat percentage by 0.8 percentage units, only a slight trend was observed in mean rumen $\mathrm{pH}$.

Impact of treatments on concentration of ruminal $\mathrm{N}-\mathrm{NH}_{3}$ was not significant (Table 3). As cellulytic bacteria mainly need $\mathrm{NH}_{3}$ as a source of $\mathrm{N}$, in this study, ruminal $\mathrm{N}-\mathrm{NH}_{3}$ concentration probably did not limit microbial growth, because reduction of particle size increased DMI.

Total VFA, acetate and propionate concentration, and acetate:propionate ratio were affected by forage particle size. Only subtle changes in molar proportions of butyrate, isobutyrate, valerate, and isovalerate were detected (Table 3). Because of greater ruminal fermentability of the medium and fine alfalfa treatments, they had greater concentration of total VFA $(P=0.003)$ and propionate $(P=0.002)$, and smaller acetate $(P=0.004)$ and acetate:propionate ratio $(P=$ 0.002 ) than long alfalfa treatment (Table 3 ). Reduction of particle size increased surface area of particles and their fermentability, therefore concentration of total VFA and propionate increased in medium and fine alfalfa treatments compared with long alfalfa treatment. In addition, reduction of NDF digestion (Table 2) resulted in increased passage rate and decreased RMRT (Table 3), and decreased concentration of acetate. There is little evidence showing that forage particle size affects rumen $\mathrm{pH}$ and VFA concentration. Diets of coarse particle size result in an increased tendency to sorting, and it is likely that, even if mean rumen $\mathrm{pH}$ and VFA values are not different, diurnal patterns may be, resulting in a less consistent rumen environment (Kononoff, 2002).

Reduction of particle size increased the particulate ruminal passage rate $(P=0.002)$, but decreased RMRT $(P=0.002)$, lower compartment mean retention time
$(P<0.0001)$, and time delay of markers $(P<0.0001$; Table 3). Reduction of forage particle size increased their FSG (Table 1). The value of FSG of particles in long, medium, and fine alfalfa treatments was 1.391, 1.467, and 1.557, respectively, and the value of GM was $3.34,2.47$, and $1.66 \mathrm{~mm}$, respectively. Kaske and Engelhardt (1990) found that in the normal density range of digesta particles ( 0.8 to $1.5 \mathrm{~g} / \mathrm{mL}$ ), particle size affected passage rate and RMRT. They found a clear negative relationship between particle density and RMRT, and found a linear relationship between particle size and RMRT of particles in the forestomach. In the current experiment, the correlation coefficients of FSG of TMR and forage with RMRT were -0.73 and -0.64 , respectively (Table 6). Particles with a low density are retained considerably longer (52 to $91 \mathrm{~h}$ ) in the reticulorumen than particles with a high density (19 to $44 \mathrm{~h}$ ) (Kaske and Engelhardt, 1990). The results show that RMRT are 2.25 and $11 \%$ lower in the medium and fine alfalfa treatments, respectively, than in the long alfalfa treatment (Table 3). In addition, reduction of time delay was the result of increased passage rate (Murphy et al., 1989; Kaske and Engelhardt, 1990).

Chewing behavior. Reducing alfalfa particle size resulted in decreased time spent eating $(P<0.039)$, ruminating $(P<0.0001)$, and total chewing activity $(P$ $<0.0001$; Table 4). Cows spent 258, 233, and $209 \mathrm{~min} /$ d (Table 4) eating in long, medium, and fine alfalfa treatments, respectively. According to Beauchemin (1991), these results were within the normal range. The reduction of GM of TMR from 3.34 in the long alfalfa treatment to 2.47 and 1.66 (26 and 50\% reduction) in the medium and fine alfalfa treatments, respectively, caused a decrease of 10 and $19 \%$ in time spent eating (Table 4). When time spent eating was expressed as per daily intake (kg) of DM, NDF, peNDF > 1.18, peNDF PSPSoriginal, $_{\text {, peNDF }}$ PSPSnew $_{1}, \mathrm{ADF}, \mathrm{NFC}$, and BW (Table 4), reduction of alfalfa particle size decreased eating time for all components of diet and BW (Table 4).

Time spent ruminating ranged from 236 to $339 \mathrm{~min} /$ $\mathrm{d}$ (Table 4); these values are consistent with the normal range of 4 to $7 \mathrm{~h}$ for dairy cows eating 4 to $6 \mathrm{~kg} /$ $\mathrm{d}$ of NDF (Beauchemin, 1991). However, the diets used in treatments had 33\% NDF based on DMI. Cows fed large alfalfa particles at this level of NDF spent more time than the normal range (long alfalfa treatment; Table 4). Cows spent 8.65, 4.77, and $3.94 \mathrm{~h} / \mathrm{d}$ in rumination of long, medium, and fine alfalfa treatments, respectively. Rumination time was 15.6 and $30 \%$ lower for medium and fine alfalfa treatments, respectively, than for long alfalfa treatment (Table 4). The function of rumination is to work over feed until it can escape 
the cycle of regurgitation and pass into the abomasum for further digestion. In this experiment, reduction of particle size decreased time spent ruminating (Table 4), RMRT (Table 3), and passage rate of particulate material (Table 3 ). In addition, decreased time spent ruminating reduced ruminal digestion of fiber fraction (Table 2), and ultimately depression of milk fat percentage (Table 5). Beauchemin et al. (1997) reported that increasing fiber level and forage particle size effectively increased rumination, resulting in increased salivation, rumen $\mathrm{pH}$, acetate: propionate ratio, and milk fat.

Reducing alfalfa particle size decreased total chewing activity (Table 4). In medium and fine alfalfa treatments, total chewing activity was 13 and $25 \%$ lower, respectively, than in the long alfalfa treatment. Reducing alfalfa particle size decreased rumination and total chewing activity per daily intake $(\mathrm{kg})$ of $\mathrm{DM}$, NDF, peNDF $_{>1.18}$, peNDF PSPSoriginal, $_{\text {peNDF }}$ PSPSnew, $\mathrm{ADF}$, NFC, and BW (Table 4). Mertens (1997) suggested that the ratio of total chewing activity to DM is an attribute of a feed, and varies with breed, size, and level of intake or fiber content. In this experiment, the ratio of total chewing activity to peNDF provides a more consistent measure of pef than the ratio of total chewing activity to DM or NDF (Table 4). In addition, the ratio of total chewing activity to peNDF $>1.18$ and peND$\mathrm{F}_{\text {PSPSnew }}$ provides a more consistent measure of pef than the ratio of total chewing activity to peNDF PSPSori- $_{\text {- }}$ ginal (Table 4). Reduction of particle size was due to a decreased proportion of peNDF $>1.18$, peNDF $_{\text {PSPSoriginal }}$, and peNDF PSPSnew $_{\text {, but increased intake of them was }}$ the result of increased DMI (Table 2). Therefore, reduction of particle size decreased the ratio of rumination and total chewing activity time to peNDF $>1.18$, peNDFPSPSoriginal and peNDF PSPSnew $_{\text {in the medium and fine }}$ alfalfa treatments compared with the long alfalfa treatment (Table 4). Estimated pef $f_{\text {PSPSoriginal was sig- }}$ nificantly lower than other effectiveness systems, therefore the ratio of pef $f_{\text {PSPSoriginal }}$ to time spent eating, rumination, and total chewing activity were considerably higher than peNDF $>1.18$ and peNDF ${ }_{\text {PSPSnew. The }}$ results were similar to those of Beauchemin et al. (1997), Grant et al. (1990), and Le Liboux and Peyraud (1990). The need for mastication increases as quantity of slowly digestible DM, NDF intake, and proportion of forage (Mertens, 1997, 2000) in diet increases, but decreases by grinding of forage (Le Liboux and Peyraud, 1990). In the current study, the diets had the same sources and amount of NDF and the ratio of forage to concentrate was similar between the treatments. Therefore, the reduction of forage particle size was the most influential factor affecting chewing activity. In addition, in this study, there was not high corre- lation between total chewing activity/rumination time and the proportion of particles larger than $19 \mathrm{~mm}(\mathrm{r}=$ 0.18 and $\mathrm{r}=0.22$, respectively). However, Kononoff (2002) suggested that increasing the proportion of particles larger than $19 \mathrm{~mm}$ may be a primary factor affecting total chewing activity in dairy cattle fed diets containing alfalfa hay as the forage source.

Production and composition of milk. Reduction of particle size had no effect on milk yield and $4 \%$ FCM yield ( $P=0.128, P=0.488$, respectively; Table 5). Diets were balanced using the NRC (2001) model for nutrient requirements of dairy cows. Based on simulation, RDP and RUP of diets had positive balance (204 and $128 \mathrm{~g} / \mathrm{d}$, respectively). It is possible that milk production may have, in part, been limited due to the cost of metabolizing excess RDP and RUP, but more likely due to inadequate RUP in rations.

Reducing particle size reduced fat $(P<0.0001)$, but increased CP content of milk ( $P=0.004$; Table 5). Grant et al. (1990) reported that milk fat percentage increased with increasing particle size. A decrease in $\mathrm{NDF}$ digestibility, decreased ruminal $\mathrm{pH}$, decreased total chewing activity and rumination time, and decreased acetate: propionate ratio by reduction of alfalfa particle size were influential factors affecting milk fat and protein (Shaver et al., 1988; Armentano and Pereira, 1997; Mertens, 1997). In midlactation, milk fat is a good indicator of optimal rumen fermentation, ruminal $\mathrm{pH}$ levels, and effective fiber (Armentano and Pereira, 1997). Mertens (1997) reported that ruminal fermentation is altered and milk fat percentage is depressed when the forage in ration is finely ground or chopped. However, Beauchemin et al. (1997) found that processing forages reduced rumination time by 52 to $62 \%$ with minimal effect on milk fat percentage, and suggested that fat content itself was not a suitable indicator of effective fiber. In addition, low fiber diets may not always result in low milk fat tests. Le Liboux and Peyraud (1990) observed depression of milk fat with reduced feed particles when diets contained less than 28\% NDF. However, in this experiment, diets contained about $33 \%$ NDF in treatments.

\section{Functional Specific Gravity and PEF}

The correlation between animal response variables and their $P$-values are represented in Table 6 . The correlations between NDF intake $(\mathrm{kg})$ and milk fat (\%), ruminal $\mathrm{pH}$, total chewing activity (min), peNDF $_{>1.18}(\mathrm{~kg})$, and RMRT (h) were highly negative. There was higher correlation between $\operatorname{peNDF}_{>1.18}(\mathrm{~kg})$ and milk fat (\%), ruminal $\mathrm{pH}$, and total chewing activity $(0.78,0.66$, and 0.77 , respectively) than NDF intake $(-0.70,-0.70$, and -0.76 , respectively). The correlation 
coefficient between NDF intake and peNDF $>1.18$ is representative of pef because the $\operatorname{peNDF}_{>1.18}$ is a discounted NDF according to particle size (Mertens, 1997). In this experiment, peNDF provided a more consistent measure of pef than NDF (Table 4). Increased NDF intake result of reduction of particle size could not maintain milk fat, ruminal $\mathrm{pH}$, and total chewing activity at an optimum level. Therefore, peNDF $_{>1.18}$ intake accounted more variation in milk fat, ruminal $\mathrm{pH}$, and total chewing activity on optimum level (Table 6).

Daily intake of NDF had a high positive correlation to FSG of TMR and forage, but peNDF $>1.18$ had a high negative correlation to FSG of TMR and forage (Table 6); these high correlations resulted in FSG and DMI increasing with reduction of particle size (Table 1 and 3 ).

Functional specific gravity of TMR and forage had high negative correlation with RMRT but the correlation with forage FSG was lower than with TMR (-0.64 vs. -0.73; Table 6). Kaske and Engelhardt (1990) found that there was a clear negative relationship between particle density and RMRT, and a linear relationship between particle size and RMRT of particles in the rumen. Low correlation between chewing activity and the RMRT confirmed that particle size reduction was not a rate-limiting step in passage rate or retention in rumen. In addition, negative high correlation of FSG of TMR and forage with milk fat, ruminal $\mathrm{pH}$, total chewing activity, and TMRT is the result of reduced daily intake of peNDF $>1.18$ due to reduction of particle size (Table 2). There was a negative correlation between FSG of forage and TMR to RMRT (Table 6). As particles must be retained in the rumen to be effective, this highly negative correlation shows that FSG can be used as a discount factor for NDF on accurate measurement of pef.

The FSG of TMR accounted for 46.1, 52.0, 44.6, 40.1, and $73.2 \%$ of the variation in total chewing activity $(\mathrm{min} / \mathrm{d})$, rumination time $(\mathrm{min} / \mathrm{d})$, milk fat $(\%)$, ruminal liquid $\mathrm{pH}$, and peNDF intake $(\mathrm{kg} / \mathrm{d})$, respectively. Functional specific gravity of forage accounted for 73.1, $83.2,68.3$, and $48.6 \%$ of the variation in total chewing activity ( $\mathrm{min} / \mathrm{d})$, rumination time ( $\mathrm{min} / \mathrm{d})$, milk fat (\%), and ruminal liquid $\mathrm{pH}$. However, the regression coefficients for FSG of forages were higher than for the FSG of TMR. The regression coefficients were very close when NDF intake (kg) and NDF of forage were fitted with total chewing activity, rumination time, milk fat, and ruminal $\mathrm{pH}(57.0,58.0,0.48$ and 0.48 vs. $57.0,58.2,47.7$ and 48.4 , respectively). The

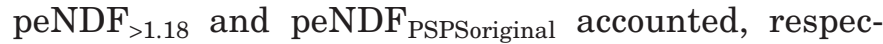
tively, for 59.0, 72.2, 74.0, and 50.0\%, and 70.0, 81.9, 63.0 , and $41.1 \%$ of variation of total chewing activity $(\mathrm{min} / \mathrm{d})$, rumination time $(\mathrm{min} / \mathrm{d})$, milk fat $(\%)$, and ruminal liquid $\mathrm{pH}$, respectively. Ratios of $\mathrm{peNDF}_{>1.18^{-}}$ to-FSG of TMR and peNDF $>1.18$-to-FSG of forage had greater coefficients than peNDF $>1.18$ and accounted, respectively, for $59.0,70.5,67.7$, and $48.3 \%$, and 65.0 , $78.5,73.3$, and $50.3 \%$ of variation of total chewing activity $(\mathrm{min} / \mathrm{d})$, rumination time ( $\mathrm{min} / \mathrm{d})$, milk fat $(\%)$, and ruminal liquid $\mathrm{pH}$. Ration of peNDF $\mathrm{PSPSoriginal}$-to-

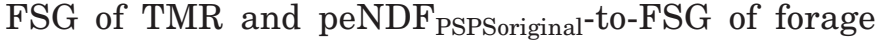
accounted, respectively, for $69.4,80.3,60.5$, and $40.0 \%$, and $70.2,81.6,61.4$, and $40.0 \%$ of variation of total chewing activity $(\mathrm{min} / \mathrm{d})$, rumination time $(\mathrm{min} / \mathrm{d})$, milk fat (\%), and ruminal liquid $\mathrm{pH}$, respectively. Using these ratios increased the regression coefficients for estimation of animal variables.

Ruminants require forage fiber in coarse physical form (NRC, 2001). The time spent chewing per unit of DM could be used as an index of roughage value (Balch, 1971). Mertens (1997) reported that NDF is the nutritional component of roughage that is related to total chewing activity. Santini et al. (1983) proposed that fiber (or roughage) intake must be adjusted by mean particle length to create a roughage index that more closely corresponds to total chewing activity. Mertens (1997) introduced the concept of peNDF as the fiber portion of the diet that stimulated chewing activity and that is responsible for formation of the rumen mat. Increasing fiber level and forage particle size has been shown to effectively increase total chewing activity, resulting in increased saliva flow, rumen $\mathrm{pH}$, acetate to propionate ratio, and milk fat levels (Beauchemin et al., 1997). However, there are other physical properties of feeds (particle size distribution, particle shape, fragility (Mertens, 2000), moisture, FSG (Wattiaux, 1990), cation exchange capacity, buffering capacity (Hooper and Welch, 1985), and rate of fermentation (Mertens, 1997) that influence effectiveness of fiber. Ultimately these effects should be quantified and incorporated empirically into the peNDF system. These results emphasize that inserting a discount factor based on FSG of forage for prediction of pef is suitable but more research is needed.

\section{CONCLUSIONS}

In this study, reduction of particle size increased bulk density, FSG, and the rate of hydration, but decreased WHC of alfalfa. and pef of TMR in 3 effective systems. Reduction of particle size increased DMI, NDF intake, and ruminal particle passage rate, but decreased proportion of peNDF in TMR, digestibility of NDF and ash, RMRT, acetate: propionate ratio, rumen $\mathrm{pH}$, total chewing activity, rumination time, and milk fat. The ratio of total chewing activity to peNDF pro- 
vides a more consistent measure of pef than the ratio of total chewing activity to DM or NDF. In addition, the ratio of total chewing activity to $\mathrm{peNDF}_{>1.18}$, peNDF ${ }_{\text {PSPSnew }}$ provides a more consistent measure of pef than the ratio of total chewing activity to peNDF PSPSoriginal. $_{\text {. }}$

Because not all sources of NDF are equal, a method to discount fiber relative to some standard is a necessary part of any fiber requirement system. The pef measurement is used as a discount factor of NDF and this discount factor is applied with peNDF system (adjusted NDF based on particle size). The peNDF is believed to be highly resistant to passage from the rumen and therefore stimulates chewing and mat formation. The results of this experiment emphasize that particle size of forage or TMR cn influence not only pef, but also the FSG of forage or TMR. Previous effectiveness systems confound FSG and particle size effects. As such as particle size, FSG must be used for discounting of NDF in each effective system. However, more research is needed to determine how changes in FSG of forage and TMR affected rumen conditions, how initial FSG of forage and TMR affects distribution of particle size, and how FSG and particle size in one empirical model to allow on-farm measurement of pef.

\section{ACKNOWLEDGMENTS}

This experiment was carried out at the dairy barn of University of Ferdowsi, Iran. The authors thank Fariba Vahmian and Farah Vahmian for preparation of the Cr-mordanted marker of forage particles. The authors thank Mr. Mousa, Esmaiel Teimouri, A. Mahdavi, and H. Heydarian for their assistance, and the staff of the dairy unit for care of the cows and for sample collection.

\section{REFERENCES}

Allen, M. S. 2000. Effects of diet on short-term regulation of feed intake by lactating dairy cattle. J. Dairy Sci. 83:1598-1624.

Allen, M. S., and D. R. Mertens. 1988. Evaluation constraints on fiber digestion by rumen microbes. J. Nutr. 118:261-270.

American Society of Agricultural Engineers (ASAE). 2002. Method of determining and expressing particle size of chopped forage (S424.1). Am. Soc. Agric. Eng., 70th ed. St. Joseph, MI.

Armentano, L., and M. Pereira. 1997. Measuring the effectiveness of fiber by animal response trials. J. Dairy Sci. 80:1416-1425.

Association of Official Analytical Chemists. 2002. Official Methods of Analysis. Vol. 1. 17th ed. AOAC, Arlington, VA.

Balch, C. C. 1971. Proposal to use time spent chewing as an index of the extent to which diets for ruminants possess the physical property of fibrousness characteristic of roughages. Br. J. Nutr. 26:383-394.

Beauchemin, K. A. 1991. Effects of dietary neutral detergent fiber concentration and alfalfa hay quality on chewing, rumen function, and milk production of dairy cows. J. Dairy Sci. 74:3140-3151.
Beauchemin, K. A., L. M. Rode, and M. V. Eliason. 1997. Chewing activities and milk production of dairy cows fed alfalfa as hay, silage, or dried cubes of hay or silage. J. Dairy Sci. 80:324-333.

Giger-Reverdin, S. 2000. Characterization of feedstuffs for ruminants using some physical parameters. Anim. Feed Sci. Technol. 86:53-69.

Grant, R. J., V. F. Colenbrander, and D. R. Mertens. 1990. Milk fat depression in dairy cows: Role of particle size of alfalfa hay. J. Dairy Sci. 73:1823-1833.

Grovum, W. L., and V. J. Williams. 1973. Rate of passage of digesta in sheep. 4. Passage of markers through the alimentary tract and the biological relevance of rate-constants derived from changes in concentration of markers in feces. Br. J. Nutr. 30:231-242.

Hooper, A. P., and J. G. Welch. 1985. Effects of particle size and forage composition on functional specific gravity. J. Dairy Sci. 68:1181-1188.

Kaske, M., and W. V. Engelhardt. 1990. The effect of size and density on mean retention time of particles in the gastrointestinal tract of sheep. Br. J. Nutr. 63:457-465.

Kononoff, P. J. 2002. The effect of ration particle size on dairy cows in early lactation. Ph.D. Thesis. The Pennsylvania State Univ.

Lammers, B. P., D. R. Buckmaster, and A. J. Heinrichs. 1996. A simple method for the analysis of particle sizes of forages and total mixed rations. J. Dairy Sci. 79:922-928.

Le Liboux, S., and J. L. Peyraud. 1999. Effect of forage particle size and feeding frequency on fermentation patterns and sites and extent of digestion in dairy cows fed mixed diets. Anim. Feed Sci. Technol. 76:297-319.

Merchen, N. R., J. L. Firkins, and L. L. Berger. 1986. Effect of intake and forage level on ruminal turnover rates, bacterial protein synthesis and duodenal amino acid flows in sheep. J. Anim. Sci. 62:216-224.

Mertens, D. R. 1997. Creating a system for meeting the fiber requirements of dairy cows. J. Dairy Sci. 80:1463-1481.

Mertens, D. R. 2000. Physically effective NDF and its use in dairy rations explored. Feedstuffs 72:11-14.

Murphy, M. R., P. M. Kennedy, and J. G.Welch. 1989. Passage and rumination of inert particles varying in size and specific gravity as determined from analysis of fecal appearance using multicompartment models. Br. J. Nutr. 62:481-492.

National Research Council. 2001. Nutrient Requirements of Dairy Cattle. 7th rev. ed. Natl. Acad. Sci., Washington, DC.

Poppi, D. P., B. W. Norton, D. J. Minson, and R. E. Hendricksen. 1980. The validity of the critical size theory for particles leaving the rumen. Agric. Sci. (Camb.) 94:275-280.

Santini, F. J., A. R. Hardie, and N. A. Jorgensen. 1983. Proposed use of adjusted intake based on forage particle length for calculation of roughage indexes. J. Dairy Sci. 66:811-820.

SAS Institute. 1998. User's Guide: Statistics. Version 8.2. SAS Inst., Inc., Cary, NC.

Shaver, R. D., A. J. Nytes, L. D. Satter, and N. A. Jorgenson. 1988. Influence of feed intake, forage physical form, and forage fiber content on particle size of masticated forage, ruminal digesta, and feces of dairy cows. J. Dairy Sci. 71:1566-1567.

Siciliano-Jones, J., and M. R. Murphy. 1991. Specific gravity of various feedstuffs as affected by particle size and in vitro fermentation. J. Dairy Sci. 74:896-898.

Uden, P., E. Colucci, and P. J. Van Soest. 1980. Investigation of chromium, cerium, and cobalt as markers in digesta rate of passage studies. J. Sci. Food Agric. 31:625-632.

Van Soest, P. J., J. B. Robertson, and B. A. Lewis. 1991. Methods for dietary fiber, neutral detergent fiber, and non-starch polysaccharide in relation to animal nutrition. J. Dairy Sci. 74:35833597.

Wattiaux, M. A. 1990. A mechanism influencing passage of forage particles through the reticulo-rumen: change in specific gravity during hydration and digestion. Ph.D. Thesis. Univ. of Wisconsin, Madison. 